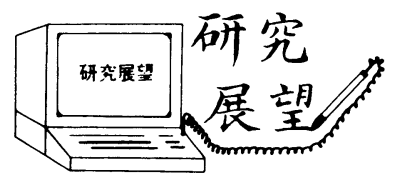

日本機械学会論文集 (B 編)

74 巻 747 号 $(2008-11)$

高温面の急速冷却における伝熱特性*

門出 政 則*1

\title{
Heat Transfer Characteristics during Quench of High Temperature Material
}

\author{
Masanori MONDE*2 \\ ${ }^{* 2}$ Department Mechanical Engineering, Saga University, \\ 1 Honjo, Saga-shi, Saga, 840-8502 Japan
}

Key Words: Quench, Transient Cooling High Temperature, Heat Transfer, Jet Impingement, Homogeneous Nucleation

\section{1. は じめに}

高温面の非定常冷却現象は, 連続鋳造, 圧延, 焼き 入れ等の材料製造過程, 原子炉の緊急炉心冷却時の再 冠水現象などに関連して過去 40 年以上に亘って数多 く研究されている. また, 最近 ITER 計画で設計中の 核融合炉の安全基準(プラズマ対向面の安全解析)の推 定においてもその重要性が高まっている，ところで， 高温面を急速冷却するときの高温面の温度基準とし て，一般に Leidenfrost 温度が使用される.すなわち， Leidenfrost 温度以上の固体表面に液体が接触したと き，固液の安定な接触が可能であるかどうかを判定す る基準の 1 つとして Leidenfrost 温度が考えられてい る.そして, Leidenfrost 温度以上の高温面が冷却さ れるとき,一般に固液の安定な接触は存在せず, 高温 面は安定な蒸気膜で覆われた状態で徐々に冷却されて いると思われている.その結果, 高温面温度が Leidenfrost 温度以下になると不安定な固液の接触が 局所的に始まる，表面温度の降下につれて，局所的だ った濡れ状態は拡大し, 終いには, 安定な核沸騰状態 となる.その後, 核沸騰は休止し, 最終的には, この 冷却過程は, 単相強制対流熱伝達となる. 高温面が噴 流や液滴などの衝突する領域と比較して相対的に大き い場合，いくつかの異なる熱伝達様式が高温面上に共 存するという複雑な非定常冷却となっているのが特徵 である，特に，膜沸騰から核沸騰へ遷移するとき，表

* 原稿受付 2008 年 7 月 24 日, 英文誌: Journal of Thermal Science and Technology, Vol. 3, No. 2, pp. 292-308 (原稿受 付 2008 年 2 月 15 日)

*1 正員, フェロー, 佐賀大学海洋エネルギー研究センター (区 840-8502 佐賀市本庄町 1).

E-mail : monde@me.saga-u.ac.jp
面の濡れ状態も大きく変化すると同時に, 熱流束や表 面温度も短時間に大きく変動するため, その特性の解 明をより一層困難にしている. その上, 安定な固液の 接触が確立される条件については, 現在でも十分な理 解が得られていない状況と言っても過言でない.

門出ら ${ }^{(1) \sim(3)}$ は，まず高温面の急速冷却現象中の表 面温度や熱流束を正確に推定するために必要となる測 定法の 1 つとして, 逆問題解に注目した解析を行い, 表面温度と熱流束を正確に推定する方法を最近確立し た.しかし, 逆問題解析で必要となる固体内の温度測 定では, 測定点が表面からある程度離れているために, 表面での高周波温度変動は, 減衰してしまい, 測定の 制約上数 $\mathrm{Hz}$ の温度変動成分しか得られず, 0.1 秒程 度の平均值での表面温度と表面熱流束しか得られなか った。そのような状況下で得られた表面温度と熱流束 の関係を基に, 固液の安定な接触開始の条件や安定な 固液接触面の移動, さらには固液接触面の移動中に出 現する最大熱流束と流動状況の関連について, 門出 ら (4) (10) は詳細な検討を進めている.

本展望では, 衝突噴流沸騰系での高温面の急速冷却 で得られた結果について概説し, 濡れ開始と均一自発 核生成について検討した結果について言及する。

\section{主 要 記 号}

$$
\begin{aligned}
c & : \text { 比熱 } \mathrm{J} / \mathrm{kg} / \mathrm{K} \\
d & : \text { 噴流径 } \mathrm{mm} \\
h_{\mathrm{g}} & : \text { 蒸発潜熱 } \mathrm{kJ} / \mathrm{kg} \\
J a & : \text { ヤフコ一数 }=\rho_{1} c \Delta T_{\mathrm{sub}} /\left(\rho_{\mathrm{g}} h_{\mathrm{gg}}\right) \\
q & : \text { 熱流束 } \mathrm{MW} / \mathrm{m}^{2} \\
q_{\mathrm{c}} & : \text { 噴流沸騰系の限界熱流束 } \mathrm{MW} / \mathrm{m}^{2} \\
q_{\max } & : \text { 最大熱流束 } \mathrm{MW} / \mathrm{m}^{2}
\end{aligned}
$$


$q_{w}:$ 表面熱流束 $\mathrm{MW} / \mathrm{m}^{2}$

$r:$ 半径 $\mathrm{mm}$

$r^{*}$ : 滞在時間での濡れ先端位置 $\mathrm{mm}$

$r_{\mathrm{e}}$ : クラスターの臨界半径 $\mathrm{mm}$

$r_{q}: q_{\max }$ の位置 $\mathrm{mm}$

$t^{*}$ : 帯在時間 $\mathrm{s}$

$T:$ 温度 ${ }^{\circ} \mathrm{C}$

$T^{*}$ : 固液界面温度 ${ }^{\circ} \mathrm{C}$

$T_{b}$ : 高温面の初期温度 ${ }^{\circ} \mathrm{C}$

$T_{\mathrm{cr}}:$ 臨界温度 ${ }^{\circ} \mathrm{C}$

$T_{\text {lavg }}$ : クラスターの平均温度 ${ }^{\circ} \mathrm{C}$

$T_{\max }$ : 固液接触可能な最大温度 ${ }^{\circ} \mathrm{C}$

$T_{\text {sat }}$ : 飽和温度 ${ }^{\circ} \mathrm{C}$

$T_{\mathrm{hn}}$ : 均一核生成温度 ${ }^{\circ} \mathrm{C}$

$T_{\mathrm{tls}}$ : 過熱限界温度 ${ }^{\circ} \mathrm{C}$

$T_{\mathrm{w}}^{*}: t^{*}$ での表面温度 ${ }^{\circ} \mathrm{C}$

$T_{\mathrm{w}}$ : 表面温度 ${ }^{\circ} \mathrm{C}$

$u$ : 噴流速度 $\mathrm{m} / \mathrm{s}$

$u_{q}$ : 濡れ面移動中の最大熱流束 $\mathrm{m} / \mathrm{s}$ ギリシャ文字

$\lambda$ : 熱伝導率 $\mathrm{W} / \mathrm{m} / \mathrm{K}$

$\Delta T_{\text {sub }}$ : サブクール度 $1\left(=T_{\text {sat }}-T_{1}\right) \quad \mathrm{K}$

$\Delta T_{\text {sat }}$ : 過熱度 $\left(=T_{\mathrm{w}}-T_{\mathrm{sat}}\right) \quad \mathrm{K}$

$\rho:$ 密度 $\mathrm{kg} / \mathrm{m}^{3}$

添字

$g:$ 気相
$1:$ 液相
$\mathrm{s}:$ 固相

\section{2. 衝突噴流による高温面の冷却}

$2 \cdot 1$ 高温面上の流動状況図 1 は, 衝突噴流で 高温面を急速冷却したときの高温面上の流動状況の一 連の変化を示す.図 1 ( a ) は, 炭素鋼 $\left(500^{\circ} \mathrm{C}\right)$ を $80^{\circ} \mathrm{C}$ の噴流 $(u=5 \mathrm{~m} / \mathrm{s})$ で, また図 1 ( b ) は, 黄銅 $\left(550^{\circ} \mathrm{C}\right)$ を $50^{\circ} \mathrm{C}$ の噴流で泠却した図である.

図 1(a ) 加, 噴流衝突直後, 直ちに円形の輝くミ ラー状のシートとなった流れが観察される.そのシー トの最先端付近は，破膜状となっているが，その破膜 位置は丁度偏向された噴流の到達位置 $(3 \mathrm{~ms} \times 5 \mathrm{~m} / \mathrm{s}$ $=15 \mathrm{~mm}$ の位置) に対応している。そして, $3 \mathrm{~ms} \sim 30$ $\mathrm{ms}$ まで, このシート状の流れは継続している。 また， このシートの破膜は周期的に生じており, その位置は, ほほ $15 \mathrm{~mm}$ となっている。破膜後に形成された液滴 は，リング状になって飛散している，この時間帯は, 静寂で, 沸騰音が聞き取れなかった。したがって, 噴 流と高温面の接触は, ほとんど生じていないと思われ

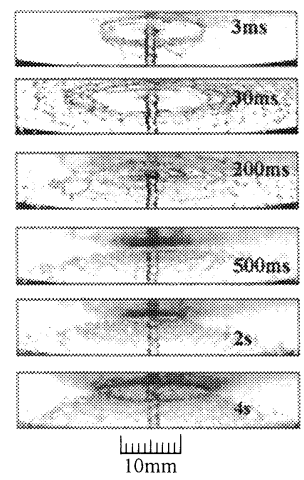

(a) Steel $\left(500^{\circ} \mathrm{C}\right)$

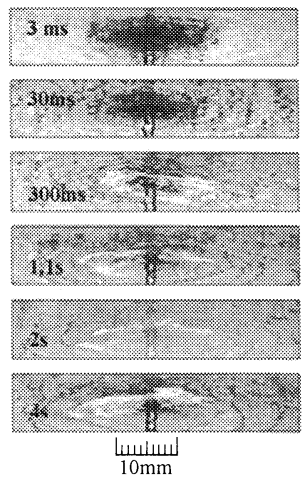

(b) Brass $\left(550^{\circ} \mathrm{C}\right)$
Fig. 1 Video clips during quenching of steel and brass blocks [(Ref.(10)]

る.ただ，中心部で固液が瞬間的に接触し，そこでの 急激な蒸気生成によって噴流は高温面上をスライドさ せられるように偏向させられ，その結果としてシート 状液膜の形成となる。そして，そのシート状の液膜流 は, ある限界位置で破膜して多くの微細な液滴となっ て流れている，なお，この様なシート状流れの破膜現 象は, 庄司の研究(11) で詳細に報告されている。

その後, 図 1(a )の $200 \mathrm{~ms}$ では, シート状の液膜は 消滅し, 激しく飛散されて液滴流となることが観察さ れる.この液滴流は, 高温面上で生成された蒸気が垂 直に激しく噴出し，かつ十分大きい運動量を保有して いるために引き起こされている. 更に, $500 \mathrm{~ms}$ では, 規則正しい傘状の飛散液滴流が観察される。また，飛 散液滴流の発生位置は, 噴流の衝突位置よりも多少広 がった位置となっており, かつ飛散液滴発生位置では, 非常に激しい沸騰が生じていることが確認される．時 間 $2 \mathrm{~s}$ と $4 \mathrm{~s}$ における飛散位置を比較すると, 飛散位 置が, 前進していることがよく分かる. 飛散位置より 内側の領域は, 液滴の飛散が見られない状況となって いる.これは, 液滴を飛散させるのに十分な蒸気が生 成されていないためである。

一方, 図1(b)の3-30 msに示される状況は, 図 1(a)のそれとは大きく異なっている.すなわち, 図 1 (b ) の $30 \mathrm{~ms}$ 以内の状況は, 噴流衝突後噴流は爆発 的に激しく飛散されている。また，破裂音も聞き取る ことができた.その後, $300 \mathrm{~ms}$ 近くで安定なシート 状の流れが現れた。このシート状の流れは, 約 $170 \mathrm{~s}$ 継続した後, 傘状の液滴流が現れた。その液滴流が時 間の経過につれて拡がる様子は, 図 1(a )とほぼ同じ であった。

なお，傘状の液滴流が現れるまでの時間や液滴流の 

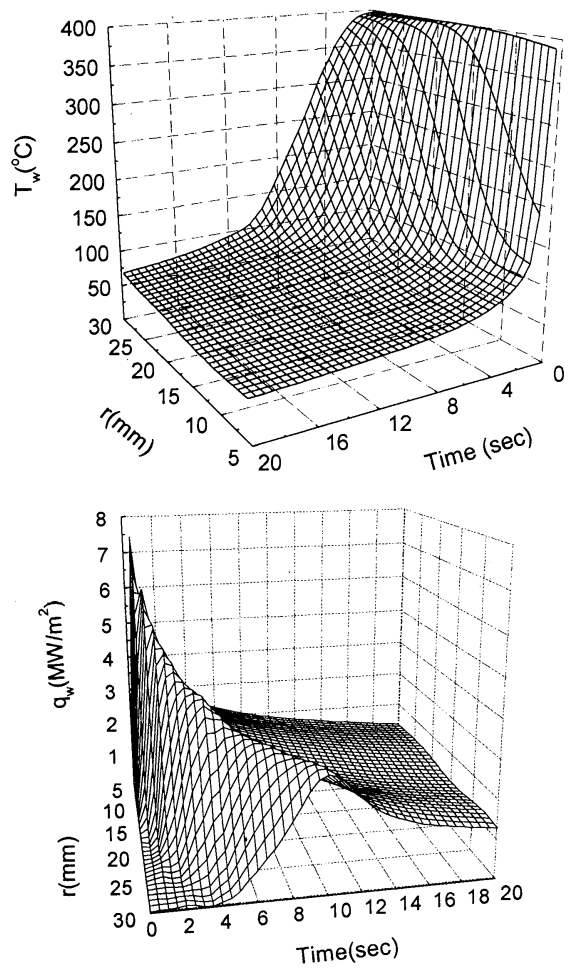

Fig. 2 Cooling curve and heat flux distribution during quenching for brass $\left(T_{\mathrm{b}}=400^{\circ} \mathrm{C}, \Delta T_{\text {sub }}=80 \mathrm{~K}, u\right.$ $=15 \mathrm{~m} / \mathrm{s}$ ) [Ref. ( 8 )]

拡がりは, 高温面の温度や材質や噴流の速度などの冷 却条件によって大きく異なることを付記しておく.

$2 \cdot 2$ 冷却中の表面温度と熱流束の変化 図 1 に 示されるような流動状況変化中に測定された固体内の 温度変化から逆問題解を利用して表面温度と熱流束を 推定した結果を図 2 亿示す。

図 2 の表面温度変化から噴流衝突後, 中心付近の表 面温度は, 2 秒以内に $400 \sim 100^{\circ} \mathrm{C}$ ま゙降下しているこ とが分かる.この間, 表面温度の急降下とともに, そ こでの熱流束は急激に増加し, 最大值に到達する. 最 大值に到達するまでの伝熱過程は, 膜沸騰状態から核 沸騰状態に推移する過程, 換言すると, 部分的に形成 される安定な濡れ状態の面積が増大する過程と言え る. 最大熱流束点を超えると, 表面は十分に濡らされ るが固体からの熱供給が減少するため, 核沸騰状態と なる. そして, この最大熱流束点は, 半径方向に移動 し始め, 安定な濡れ面積の拡大となる. 図 2 の場合で は, 最大熱流束点が高温面の周囲まで到達するのに約 10 秒かかっている. 冷却過程は, 約 10 秒で終了し, 表面温度はほぼ完全に $100^{\circ} \mathrm{C}$ 以下となっている。
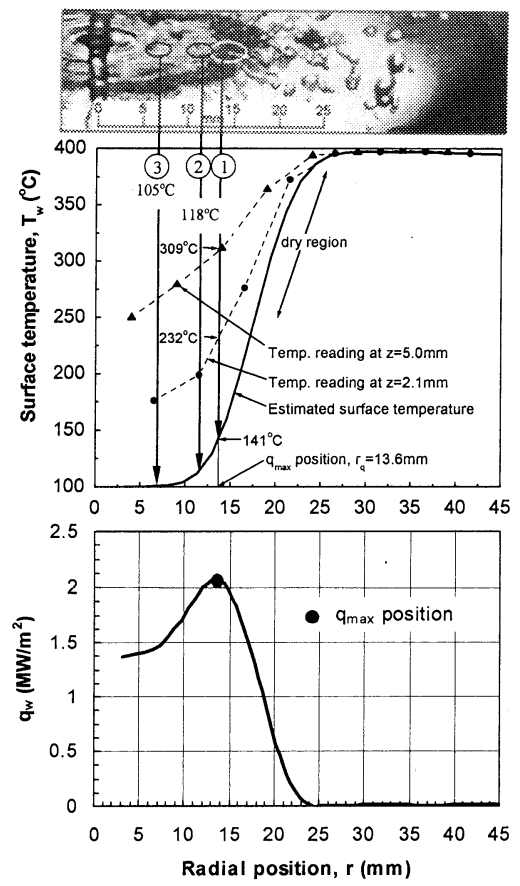

Fig. 3 Regimes of boiling and maximum heat flux during wetting front propagation $[\operatorname{Ref} .(8)]$ (Steel : $\left.T_{\mathrm{b}}=400^{\circ} \mathrm{C}, \Delta T_{\mathrm{sub}}=50 \mathrm{~K}, u=3 \mathrm{~m} / \mathrm{s}, t=4.3 \mathrm{~s}\right)$

図 3 は, 噴流衝突開始後 $t=4.3 \mathrm{~s}$ における流動状況 および表面温度と熱流束の関係を示す。図 3 中の波線 は, 測定位置(表面からの深さ) $2.1 \mathrm{~mm}$ と $5.0 \mathrm{~mm}$ で の測定温度を示す. 表面温度と熱流束は, これらの測 定温度から推定された温度である.

流動状況は, 図 3 から 3 つの領域, すなわち ( a ) 非 沸騰域 $(r=0-12 \mathrm{~mm}),(\mathrm{b})$ 激しい沸騰域 $(r=12-18$ $\mathrm{mm}),(\mathrm{c})$ 乾き域 $(r=18-45 \mathrm{~mm})$ に分割することが 出来る. 非沸騰域 $(\mathrm{a})$ では, 沸騰が強制対流熱伝達に よって抑制されているか, あるいは表面温度が十分降 下し, 沸騰が休止させられた状態となっている. 沸騰 が休止した位置は, 激しい沸騰領域の少し上流側の位 置で, 記号(2)で示されている.

最大熱流束点は, この時刻では $r=13.6 \mathrm{~mm}$ で現れ ている.この位置は, 丁度激しい沸騰領域内となって いることが図 3 から分かる. なお， $r=10-12 \mathrm{~mm} の$ 領域は, 非沸騰域となっているが, そこでの表面温度 と熱流束を考慮すると核沸騰が十分生じている筈であ るにもかかわらず沸騰が観察されていない.これは, 発生した気泡が発生後直ちにサブクール液によって凝 縮されているためである.したがって, 図 3 に示され る熱伝達の様式は, ( i ) 単相流熱伝達 $(r=0-10 \mathrm{~mm})$, 
(ii) 核沸騰域 $(r=10-14 \mathrm{~mm})$, (iii) 遷移沸騰域 $(r=$ 14-18 mm), (iv) 放射を伴う蒸気単相流熱伝達域 $(r=$ 18-47 mm)となっている.

単相熱伝達領域では，高温面の表面温度はほぼ飽和 温度となっている，例えば, 図 3 の点(3)では, 表面過 熱度は, 約 $5 \mathrm{~K} て ゙$, 単相冷却可能な条件となってい

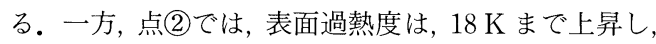
熱流束は半径方向に単調に増大し, 最大熱流束点に到 達している，最大熱流束点での表面過熱度は, $41 \mathrm{~K}$ となっている.ところで，この表面過熱度の值は，飽 和プール核沸騰における一般的な值よりも高く, サブ クール衝突噴流沸騰系での過熱度とほぼ一致している ことから, 点(2)の状態は, サブクール強制対流条件下 での核沸騰になっている。 なお，乾き域での表面温度 は約 $250^{\circ} \mathrm{C}$ か初期温度 $400^{\circ} \mathrm{C}$ まで半径の増加する方 向に急上昇している。一方, 熱流束は, 逆に半径方向 に急激に減少し，非常に小さい值となっている。

濡れ位置の移動中における表面上のある点での沸騰 状況に注目すると, 沸騰の状況は, 濡れ位置の移動に 伴って大きく変化している，すなわち，濡れ位置がそ の点に到達するまでは膜沸騰の状態が継続している が, 到達後は, 遷移沸騰を経て核沸騰になり, 最後に 単相流熱伝達となる，表面上の各点において，最大熱 流束に到達した点が, 丁度そこでの沸騰現象が遷移沸 騰から核沸騰への転向点(例えば，図 3 では， $r_{\mathrm{q}}=13.6$ $\mathrm{mm})$ となる.

ところで, Hammad ら ${ }^{(4)}$ は, 例えば冷却条件 $T_{\mathrm{b}}=$ $400^{\circ} \mathrm{C}, T_{\text {liq }}=20^{\circ} \mathrm{C}, u=15 \mathrm{~m} / \mathrm{s}$ において, 最大熱流束 点が $r=8-30 \mathrm{~mm}$ の範囲で移動しているとき, 最大熱 流束の減少につれて, 表面温度も, 約 $180-150^{\circ} \mathrm{C} の$ 範 囲で減少することおよび両者には密接な関係があるこ とを報告している．この結果から，Hammad ら(4)は， 急速冷却中に現れる最大熱流束は, 固体側から供給さ れる熱と液冷却能力の上限とのバランスで決定される ことを示唆している.

なお, Filiporic ら ${ }^{(12)}$ は平板噴流による高温面の急 速冷却を行い, 極大熱流束(彼らは, 限界熱流束と呼ん でいる)点の現れる前に非定常的な濡れの繰り返しが 生じ, その後限界熱流束点に到達すると報告してい る。

$2 \cdot 3$ 冷却曲線における流動特性と音響特性 図 4 は, 高速ビデオカメラで撮影された流動状況の変化 を示す. なお, 図 4 に示される流動状況の一連の変化 は, 初期条件 (初期温度, 液温, 噴流速度)や高温面の 材質が異なっていても共通的に現れる状況変化である が，同じ流動状況が出現する時間は，初期条件や高温

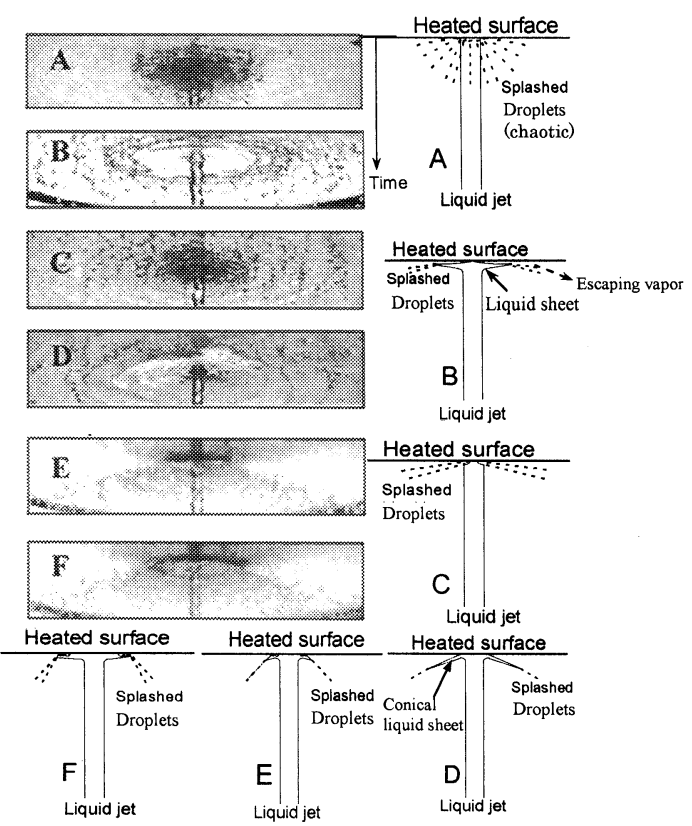

Fig. 4 Flow patterns identified from video observation and flow model [Ref.(10)]

面の材質によって大きく異なることを記しておく．

図 4 は, 6 つの異なる特徴的な流れの状況を写真 $\mathrm{A} \sim \mathrm{F}$ に示す. それぞれの特徴は，以下のように要約 することが出来る.

タイプ A：水が高温面に衝突直後から激しい不規 則な液滴の流れとなる，不規則な液滴の発生は，微細 な気泡が極微少な固液の接触中に形成されたためであ ろう。この複雑さや激しさは, 固体の熱物性值 $(\rho c \lambda)_{\mathrm{s}}$ がより大きい值や表面過熱度がより大きい值により強 く依存している.

タイプ B：加熱面中心部での固液接触で生じた蒸気 流によって噴流がシート状になって高温面上を滑らせ るように流され，その下部で安定な膜沸騰が維持され ている.約 $10 \mathrm{~mm}$ の半径位置でそのシート状の流れ は, 液滴となり, その液滴は, 加熱面に対して約 5-10 度の角度で飛散されている。

タイプ C：時間の経過につれて, 表面温度は徐々に 降下し, 固液接触の時間がより長くなることによって 大量の気泡が不規則に生成されている。その結果，噴 流は飛散液滴として外向きに大量に放出させられるよ うになる。

タイプ D：ここでは, 逆円錐状のシート状の流れが 観察される。この流れは，ある熱・流体力学的条件下 で出現すると考えられる.タイプCよりも大きい濡 


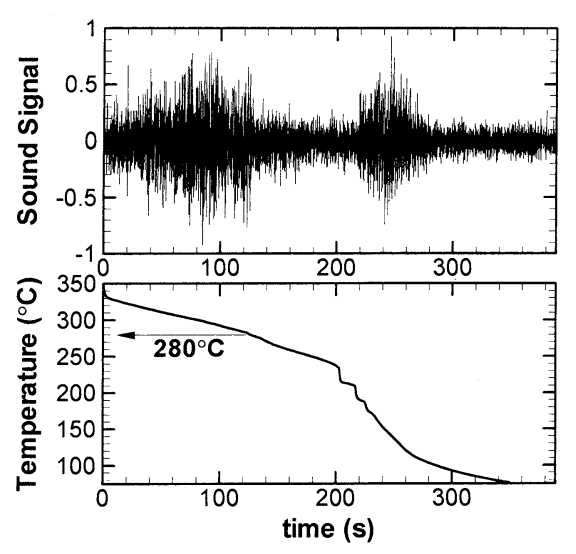

Fig. 5 Audible sound during quench and corresponding cooling curve [Ref. ( 7 )] (embedded thermocouple reading : $4 \mathrm{~mm}$ from center, $5 \mathrm{~mm}$ from surface, Copper, $T_{\mathrm{b}}=350^{\circ} \mathrm{C}, T_{\text {iiq }}=49^{\circ} \mathrm{C}, u=3 \mathrm{~m} / \mathrm{s}$ )

れ面が中心部で接触するようになり，この接触状況は， しばらく継続される. 固液接触部でより多くの気泡 (蒸気) が生成されることによって, 噴流は衝突面から 約 15-20 度近くの角度まで偏向されている.

タイプ $\mathrm{E}$ : 安定な濡れ面は噴流径の 2 倍程度まで拡 大成長しているが, その場所に滞在している. 濡れ面 は, より多くの飛散液滴を円筒状に生成している.

タイプ F : 濡れ面の表面温度は, 更に降下し, 固体 からの熱の供給が液の冷却能力よりも小さくなる.そ の結果, 濡れ面は半径方向に移動を開始するようにな る. タイプ Eと F の間の沸騰様式は, 熱流束の大き さを除くと同一である. なお,これらの流動状況は文 献(10)に詳細に説明されている.

図 5 は, 高温面に噴流が衝突以降の測定温度 (測定 位置, $r=4 \mathrm{~mm}, z=5 \mathrm{~mm})$ の変化とマイクロフォン で測定された音の強さの変動との関係を示す.すでに 述べたように流動状況の連続的な変化はそのパターン が現れる時間が異なっている点を除くとほぼ同じであ ることから, 冷却中の流動状況と対応する音の強度の 比較は, 加熱面上での蒸気の発生状況を理解する上で 貴重な情報となる. タイプ A では周期が短か過ぎて, 音の特性を明らかにできなかった。シート状流れが継 続している時間すなわち衝突開始から $50 \mathrm{~s}$ までと時 間 $120 \sim 220 \mathrm{~s}$ の間では, 図 5 (図 4 では, タイプ B, D) に示されるように非常に静寂な沸騰音となっている. タイプ $\mathrm{B}$ と D 間では, 液体は蒸気生成によって激 しく飛散されている.一方, この間の音の強さも大き くなっている，時間 $50 \sim 120 \mathrm{~s}$ での音は, 鋭く飛散さ れている液滴の形成によると考えられる. タイプ D

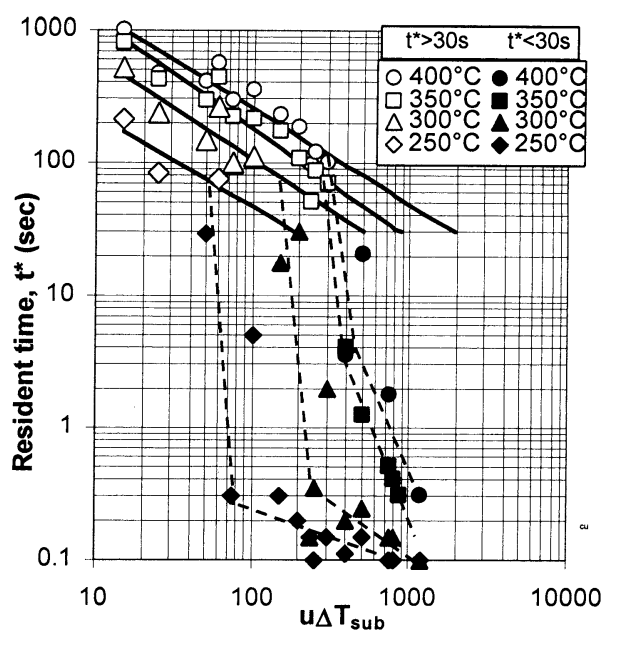

Fig. 6 Resident time, $t^{*}$ at different initial temperatures for copper plotted against $u \Delta T_{\text {sub }}$ [Ref. (6) ]

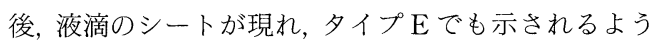
に激しい飛散液滴流となっている. その結果, 再び大 きい振幅の強い音(例えば, 図 5 の約 220 秒前後の音) が生じる.このとき, ウエッテングフロントは外向き に高温面上を移動し始める. ウエッテングフロントの 移動中も, 図 5 に示されるように激しい音が随伴され ている. 熱伝達の様式は, 最終的に強制対流に漸近す ると同時に激しい音も静寂になる.

図 5 から, 時間 $t=20-120 \mathrm{~s}$ (表面温度 $280^{\circ} \mathrm{C}$ に到達 した時刻頃)で示される短い周期でかつ大きい振幅の 音は, 非常に短い周期で需れ面と乾き面が繰り返され ていることを意味している. 一方，この間の測定温度 はほとんど変化していない.これは, 短い周期での表 面温度の変動が, 減衰して, 温度の測定位置までその 変動分として到達できないためである.

$2 \cdot 4$ 濡れ開始時間 図 5 に示されるように, 高 温面に噴流が衝突後激しい破裂音を伴う状況が継続し た後, 多少の静寂時間 $(t=140-210 \mathrm{~s})$ の経過後, 濡れ 面の位置が半径方向に拡大し始めることが確認されて いる. そこで, 安定な濡れが確保され, 濡れが拡大し 始める時間(濡れ開始時間： $t^{*}$ )を $u \Delta T_{\text {sub }}$ で整理した 結果を図 6 に示す. なお, $u \Delta T_{\text {sub }}$ は, 液側の冷却能力 を示す量と考えられるが, その物理的な意味は不明で ある・

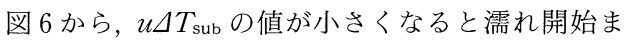
でかなりの時間がかかることが分かる.そして, $t^{*}>$ $30 \mathrm{~s}$ の範井については, $t^{*} と u \Delta T_{\mathrm{sub}}$ の間には規則性 が見られる。 


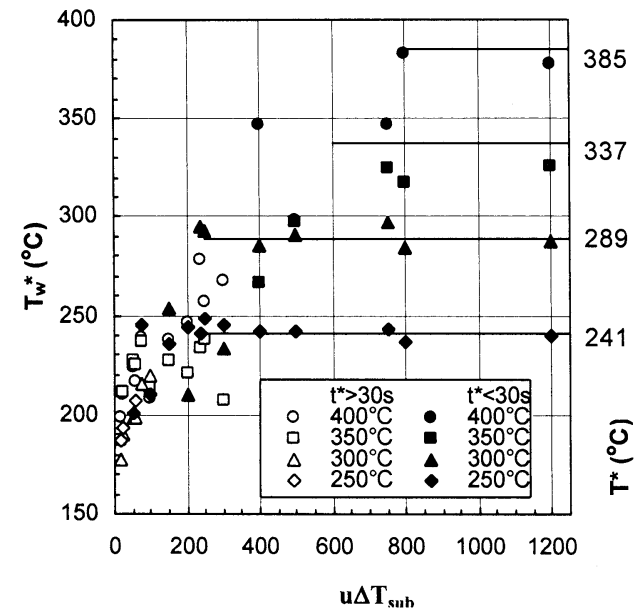

Fig. 7 Surface temperature for copper at resident time $t^{*}$

この濡れ開始時間は, 液側の冷却の大きさと固体側 からの熱の供給に大きく依存している，しかし，この 時間を支配しているメカニズムについてはまだ十分理 解できる状況にない.なお，この濡れ開始時間遅れに ついては, Piggottら(13)によってすでに同様なことが 指摘されている.

$2 \cdot 5$ 濡れ開始時刻における表面温度 図 7 は, 濡れ開始時刻における表面温度 $T_{\mathrm{w}}^{*}$ と $u \Delta T_{\text {sub }}$ との関 係を示す。なお，黄銅や炭素鋼についても同様な結果 となることを記しておく．また，図 7 中の直線は，液 温 $T_{\mathrm{liq}}$ の半無限液体が一様な半無限高温面 $T_{\mathrm{b}}$ に接触 した瞬間の表面温度で，次式で与えられる。

$$
T^{*}=\frac{T_{\mathrm{b}}-T_{\mathrm{liq}}}{1+1 / \beta}+T_{\mathrm{liq}}, \quad \beta=\sqrt{(\rho c \lambda)_{\mathrm{s}} /(\rho c \lambda)_{1}}
$$

濡れ開始時間 $t^{*}$ が $t^{*}>30 \mathrm{~s}$ では, 加熱面上の衝突 域では，安定な濡れが確保されているにもかかわらず， 濡れが広がらない状態が濡れ開始時間 $t^{*}$ まで続いて いることが報告(6)されている．濡れが広がらない原 因は，濡れ先端部での熱流束が非常に大きく，その位 置で放射状流が全て飛散されるためである. 一方, $t^{*}$ $<30 \mathrm{~s}$ では，噴流衝突後濡れ位置が半径方向にすばや く拡大を開始している。このすばやい濡れ位置の移動 は，通常比較的低い初期温度で，かつ $(\rho c \lambda)_{\mathrm{s}}$ の值が小 さい場合に生じている。また，このときの表面温度は， $u \Delta T_{\mathrm{sub}}$ の值にかかわらずほぼ一定の值となうている. そして，その值は，図 7 に示されるように式(1)に示 される固液の瞬間接触温度に漸近している. $t^{*}<30 \mathrm{~s}$ の時間 $t^{*}$ における表面温度 $T_{\mathrm{w}}^{*}$ が $T^{*}$ の温度に漸近

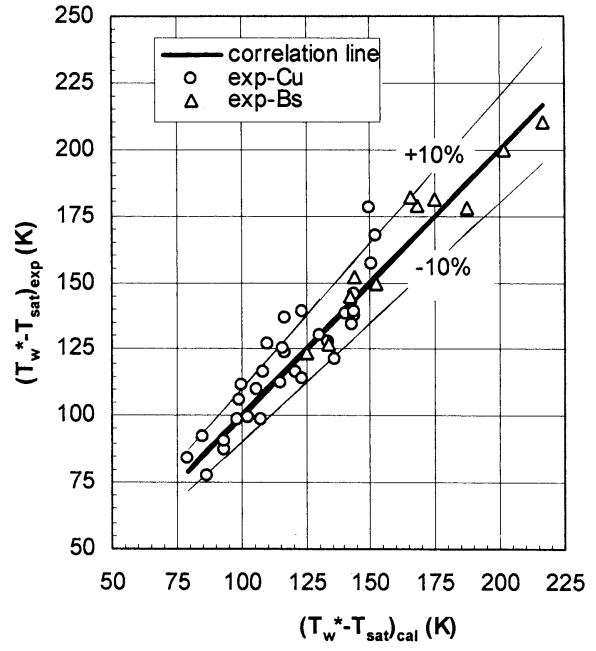

Fig. 8 Correlation for surface temperature $T_{\mathrm{w}}^{*}$ at resident time $t^{*}[\operatorname{Ref} .(6)]$

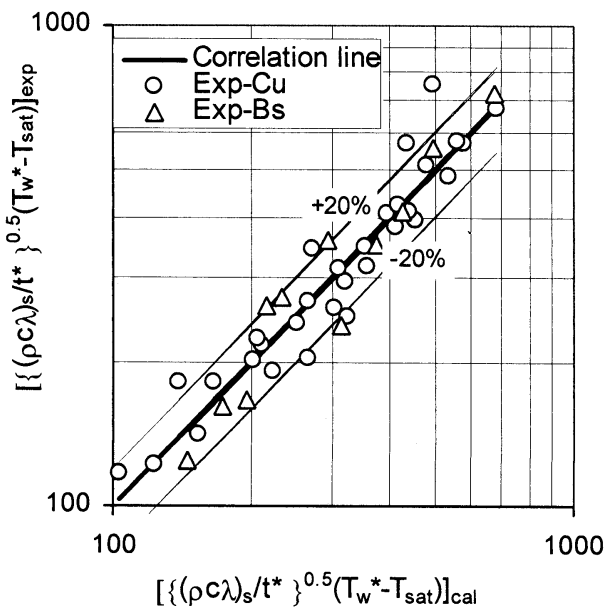

Fig. 9 Correlation for resident time $t^{*}$ [Ref. (6)]

するのは, 図 5 に示される音の変化から推察すると, 接触時間も短く，かつ固液接触の繰り返し回数が少な いために, 固体内の温度分布の崩れが小さく, 半無限 近似が適用可能であったために，表面温度(時間平均 の意味での) は固液接触温度 $T^{*} に$ 漸近したものと考 えられる。

\section{$2 \cdot 6$ 濡れ開始時刻と開始時の表面温度の関係}

図 6,7 で, $t^{*}>30 \mathrm{~s}$ における濡れ開始時間, $u \Delta T_{\mathrm{sub}}$ と表面温度の間には，かなり規則的な関係がみられる ことから，暫定的にそれらの関係を最小自乗法で決定 した式が, 式(2)，（3)で，それらを用いて整理した 結果(6) を図 8,9 に示す. 


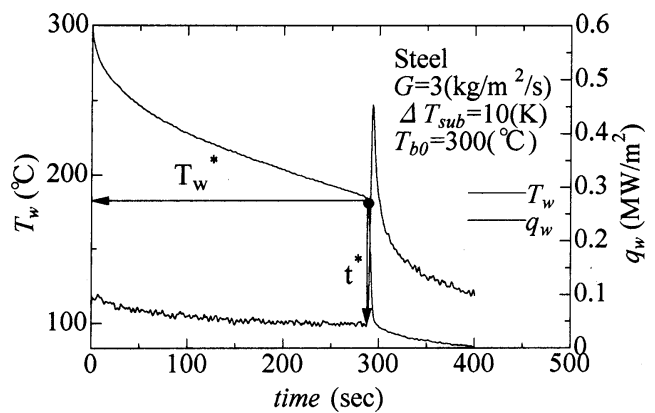

Fig. 10 Surface temperature and heat flux during spray cooling of ethanol for carbon steel (mass flux $G$ $=3 \mathrm{~kg} / \mathrm{m}^{2} / \mathrm{s}, \Delta T_{\mathrm{sub}}=10 \mathrm{~K}, T_{\mathrm{b}}=300^{\circ} \mathrm{C}$ )

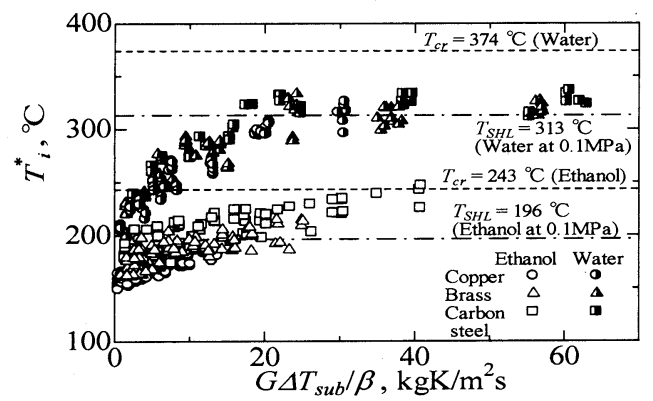

Fig. 11 Surface temperature at resident time against

$$
\begin{aligned}
& \frac{\sqrt{(\rho c \lambda)_{\mathrm{s}} / t^{*}}\left(T_{\mathrm{w}}^{*}-T_{\mathrm{sat}}\right)}{(\rho c u)_{1}\left(T_{\mathrm{sat}}-T_{\text {liq }}\right)}=14\left(\frac{2 r^{*}}{d}\right)^{0.72} \\
& \quad \times\left\{(\rho c u)_{1}\left(T_{\text {sat }}-T_{\text {liq }}\right)\right\}^{-0.41}\left(T_{\mathrm{b}}-T_{\text {liq }}\right)^{-0.99} \\
& \ldots \ldots \ldots \ldots . . . \\
& \frac{T_{\mathrm{w}}^{*}-T_{\text {sat }}}{T_{\mathrm{b}}-T_{\text {liq }}}=157\left(\frac{(\rho c \lambda)_{\mathrm{s}}}{(\rho c \lambda)_{1}}\right)^{-0.49}\left(\frac{2 r^{*}}{d}\right)^{-0.49} \\
& \quad \times\left\{(\rho c u)_{1}\left(T_{\text {sat }}-T_{\text {liq }}\right)\right\}^{0.14}\left(T_{\mathrm{b}}-T_{\text {liq }}\right)^{-0.68}
\end{aligned}
$$

ここで, $r^{*}$ は濡れ開始点半径で， $T_{\mathrm{w}}^{*}$ はそこでの表面 温度である。なお, 式 (2), (3) は, 有次元式であり, の物理的意味も含めて今後更に検討する必要がある.

図 8,9 に示されるように, 濡れ開始時刻, $u \Delta T_{\text {sub }}$ と表面温度の間にはかなり規則的な関連があることお よび式 (2)，（3)で与えられることが分かる.

参考までに，ミストで高温面を冷却したときの濡れ 開始時間における温度や熱流束の変化を図 10 , またそ のときの表面の温度と式 ( 3 ) から求められた表面温度 と $G \Delta T_{\text {sub }} / \beta$ の関係を図 11 に示す. 図 11 中の $T_{\mathrm{cr}}$, $T_{\mathrm{SHL}}$ は, それぞれ液体の臨界温度と過熱限界温度であ る.

図 10 に示されるように，ミスト冷却では高温面全
体が一様に冷却されることから温度の急降下と熱流束 の急上昇が同時に起きている。このときの表面温度 は, $G \Delta T_{\mathrm{sub}} / \beta$ が小さい範囲では, 直線的に上昇して いるが, $G \Delta T_{\text {sub }}$ が大きくなるとほぼ一定 $\left(=T_{\mathrm{SHL}}\right)$ と なっている.

図 7 と図 11 の比較から, 濡れ開始時における表面 の温度特性が $t^{*}<30 \mathrm{~s}$ での衝突噴流冷却とスプレ冷 却で大きく異なっているが，この原因については，不 明である。

\section{$2 \cdot 7$ ウエッティングフロント移動中の伝熱様式}

図 3 には, 1例としてウエッティングフロント移動中 の表面温度と熱流束の分布抒よびウエッティングフロ ント近傍の流れの様子を示した. 更に, 最大熱流束点 は, ウエッティングフロント点よりも少し後ろ(上流 側)に現れることを示した。なお, Filipovic ら(12) は, このような現象を安定な濡れへの前駆現象と呼んでい る. 前駆現象が現れる領域では, 表面温度は, 急激に 降下し, 一方熱流束は逆にウエッティングフロントと 最大熱流束点の間で急激に増加している。すなわち, 濡れの状況は, ウエッティングフロントと最大熱流束 点の間で不安定から安定な濡れ状態に推移しているこ とになる，換言すると，この領域内で遷移沸騰が生じ ていることになる。

図 2 から, 最大熱流束の值はウエッティングフロン 卜が外側に進行するにつれて減少することが分かっ た。この減少傾向は, 衝突噴流での限界熱流束が加熱 面径の増加に伴って減少する傾向と同様なことから, この限界熱流束の整理式を基本としながら, 固液界面 での熱流束の連続性を考慮して, 暫定的に式(4)を用 いて最大熱流束を整理することにした。

$$
\frac{q_{\max }}{q_{\mathrm{c}}}=1-C \sqrt{(\rho c \lambda)_{1}} / \sqrt{(\rho c \lambda)_{\mathrm{s}}}
$$
ここで,

$$
\begin{aligned}
& \frac{q_{\mathrm{c}}}{q_{\mathrm{co}}}=\frac{1+\sqrt{1+4 C_{1} J a}}{2} \cdots \cdots \ldots \ldots \ldots \ldots \ldots \ldots(4 \cdot \mathrm{b}) \\
& \frac{q_{\mathrm{co}}}{\rho_{\mathrm{g}} h_{\mathrm{g}} u}=0.221\left(\frac{\rho_{\mathrm{l}}}{\rho_{\mathrm{g}}}\right)^{0.645}\left\{\frac{2 \sigma}{\rho_{\mathrm{l}} u^{2}(D-d)}\right\}^{0.343}
\end{aligned}
$$

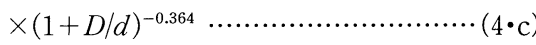

$$
\begin{aligned}
& C_{1}=\frac{0.95(d / D)^{2}(1+D / d)^{0.364}}{\left(\rho_{1} / \rho_{\mathrm{g}}\right)^{0.43}\left\{2 \sigma / \rho_{1} u^{2}(D-d)\right\}^{0.343}}
\end{aligned}
$$

また, $q_{\mathrm{c}}$ は衝突噴流沸騰系の限界熱流束, $D$ は加熱面 径, $C_{1}$ は流速や加熱面径などに関連する関数である. 最大熱流束点から中心までの距離は, ちょうど加熱面 径の半分に対応している.

式 (4)で与えられる限界熱流束は, 無限の熱源 $\left\{(\rho c \lambda)_{\mathrm{s}} \rightarrow \infty\right\}$ から熱が供給され, かつ固体側の状態に 影響を受けない，すなわち熱源の熱物性と独立である 


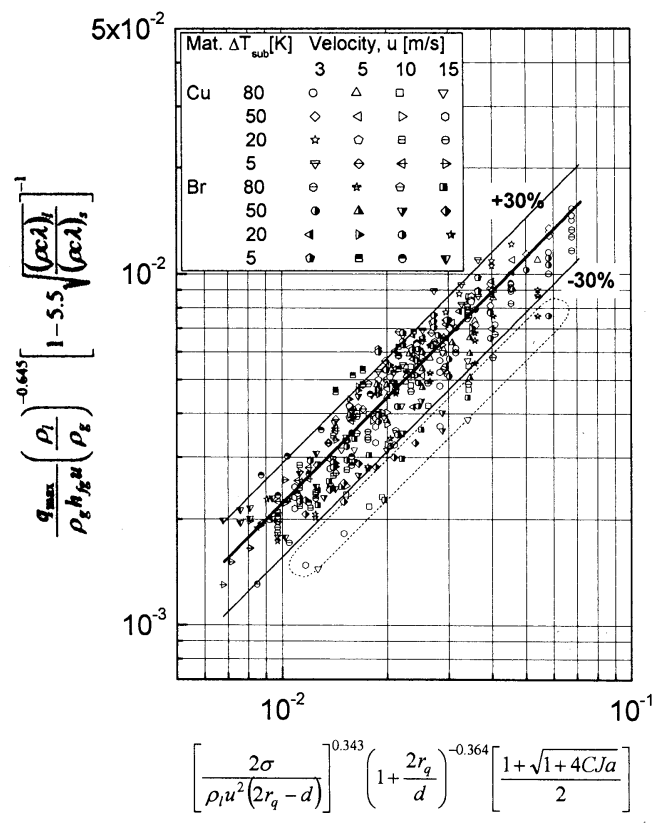

Fig. 12 Estimation of maximum heat flux during movement of wetting front based on critical heat flux for steady state condition [Ref.(8)]

という条件下で限界熱流束が発生したときの熱流束に なっている。一方, 最大熱流束は, ウエッティングフ ロントが移動中に現れた最大熱流束点での值となって いる. 図 12 亿示されるように, 最大熱流束は, 定常状 態に対する限界熱流束の式(4・b)を基本として, 式(4・ a)の $C=5.5$ の值を適用するとある程度整理できるこ とが分かる。また, $(\rho c \lambda)$ の比の值が固液の熱流束の 連続性に関連する重要なパラメーターであることを考 慮すると, 式(4・a)で最大熱流束值が整理できるとい う結果は，「ウエッティングフロントが移動中に現れ る最大熱流束は, 固体側からの熱供給能力と液側の冷 却能力のバランスから引き起こされ, 最大熱流束点の 移動は両者の熱輸送能力のバランスの崩れによって引 き起こされる.」ということを暗示している可能性が 高い。そして, 表面温度は, 両者のバランスを保つよ うに自動的に決定されている，すなわち両者の熱流束 の釣り合いをとるように変化しているとも考えられ る.

ところで，破線で囲まれたデー夕，すなわち予測值 よりも $30 \%$ 以上さいデー夕は, 高温面に噴流衝突後 直ちに安定な濡れが形成され, ウエッティングフロン トが直ぐに移動を開始するという状況下で得られたデ 一夕と炭素鋼に対するデー夕の一部である。この条件
Table 1 Critical radius and homogeneous nucleation rate for water at $20^{\circ} \mathrm{C}^{(16)}$

\begin{tabular}{|c|l|c|c|c|c|}
\hline \multirow{4}{*}{ Water } & $p_{t s}{ }^{*} \mathrm{MPa}$ & 0.5 & 0.6 & 0.7 & 0.8 \\
\cline { 2 - 6 } & $r_{\mathrm{e}} \mathrm{nm}$ & 2.91 & 2.42 & 2.08 & 1.82 \\
\cline { 2 - 6 } & $J \mathrm{~m}^{-3} \mathrm{~s}^{-1}$ & $\begin{array}{c}7.31 \\
\mathrm{x} 10^{5}\end{array}$ & $\begin{array}{c}2.74 \\
\mathrm{x} 10^{16}\end{array}$ & $\begin{array}{c}6.50 \\
\mathrm{x} 10^{22}\end{array}$ & $\begin{array}{c}8.92 \\
\mathrm{x} 10^{26}\end{array}$ \\
\hline
\end{tabular}

下で得られたデータは, ウエッティングフロントの移 動速度が一般に大きくなっていたことおよびウエッテ イングフロント近傍での濡れ幅が比較的狭くなってい たことが観測されている。このことに関連して, Woodfield ら ${ }^{(3)}$ は, 移動熱源の幅が熱電対の挿入間隔 より小さくなると測定デー夕から推定された熱流束の 值は，正しい値よりも小さくなることを逆問題解の精 度解析から指摘している. 更に, 彼らは, 移動熱源の 移動速度が早くなると測定点での時間遅れが大きくな り，移動熱源の幅が狭くなることと同様な効果となる ことを報告している．図 12 中の破線で囲まれた最大 熱流束值が, 式 $(4 \cdot a)$ の予測值より $30 \%$ 程度小さくな った原因は，逆問題解の推定誤差解析から推定すると, これらの測定データからの推定 (最大熱流束) 值が実際 の值よりも小さくなるためと考えられる.

ところで, Hall ら ${ }^{(15)}$ は, $650^{\circ} \mathrm{C}$ の炭素鋼が $25^{\circ} \mathrm{C}$ 噴 流で泠却するとき，そのウエッティングフロントが移 動中における最大熱流束を推定する式( 5 )を提案して いる。

$$
q_{\max }=q_{\mathrm{co}}\left\{1+0.952\left(\rho_{1} / \rho_{\mathrm{g}}\right)^{-0.888} \mathrm{Ja}\right\}
$$

彼らの冷却は, 準定常的で緩やかな冷却となってい た。午机故に, 最大熱流束は定常状態に近い状態で達 成されていると考えられる。

著者は, 急冷過程中に得られる最大熱流束が固体か らの熱の供給能力に強く支配されている点を考慮する と式(5)よりも式 (4)の方を推奨したい.

\section{3. 固液の安定接触と表面温度}

図 1 に示されるように, 高温面上の水は, 水が高温 面に衝突した瞬間に激しく飛散される。この飛散中, 表面上で蒸気が生成されることを意味する高い周波数 の音が確認された。更に, 発生した音の周波数は, 表 面の濡れと乾きが交互に短い周期で繰り返されている ことを暗示している.この繰り返し中の平均表面温度 は, 時間とともに減少し, 最終的には固液の安定な接 触が確立される温度まで降下する. 固液の直接接触に よって形成される蒸気の核生成は, 表面上での固液の 接触状沉が時間とともにどのように変化するのかを理 


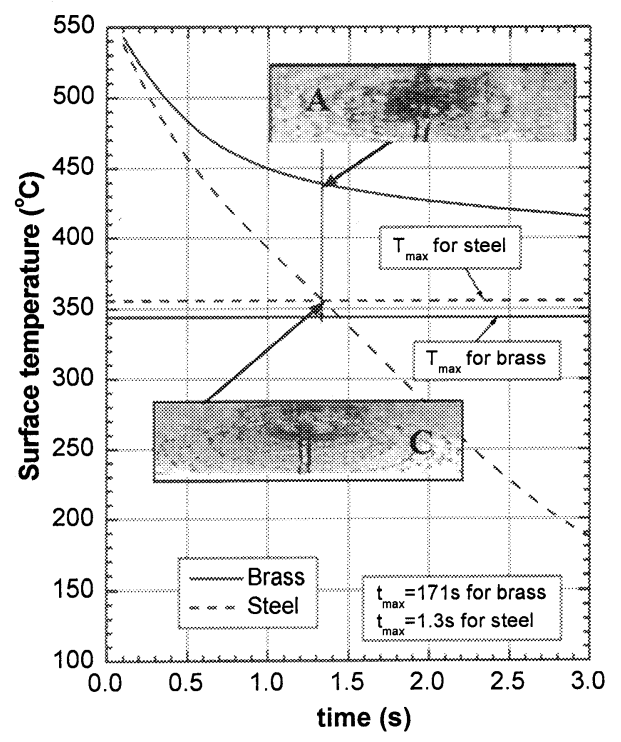

Fig. 13 Comparison of cooling curves for quenching $550^{\circ} \mathrm{C}$-brass and - steel blocks by $20 \mathrm{~K}-5 \mathrm{~m} / \mathrm{s}$ jets [Ref.(10)]

解するための重要な現象と考えることが出来る.

$3 \cdot 1$ 均質核生成均質核生成理論 ${ }^{(16) \sim(18)}$ による と, ある大きさのクラスターが一様な温度場において 液相から蒸気相に変化するために必要な最小仕事があ る. 均一核生成の状態は，この最小仕事によって決定 される.しかしながら, 核生成率は, クラスターの臨 界半径の大きさに伴って極端に変化している. 例え ば, 表 $1^{(16)}$ は, 温度 $20^{\circ} \mathrm{C}$ 水に対して, 圧力差 $p_{\mathrm{ts}}^{*}(=$ $p_{\mathrm{v}}^{*}-p_{\mathrm{L}}, p_{\mathrm{v}}^{*}:$ クラスター内の蒸気圧)で核生成が生じ たときのクラスターの大きさや核生成率を示す。ま た, 大気圧の水の核生成時のクラスタ一内の分子数は 100 個から 1000 個まで変化し, そのときの温度は $T_{\mathrm{L}} / T_{\mathrm{cr}}=0.855\left(T_{\mathrm{L}}=280^{\circ} \mathrm{C}, r_{\mathrm{e}}=4-6.5 \mathrm{~nm}\right)$ になるこ とが文献(16)に報告されている. 表 1 に示されている ように圧力差 $p_{\mathrm{ts}}^{*}$ や臨界半径はほとんど変化していな いけれども, 核生成率は, 数桁以上変化している. のような状況下で, 核生成率が適当に選択され，その 核生成率に対して均一核生成温度が推定されている.

$3 \cdot 2$ 不均一核生成 飯田ら ${ }^{(19)(20)}$ は, プール液内 の加熱面が $k=10^{7}-10^{8} \mathrm{~K} / \mathrm{s}$ で急速加熱されたときキ ヤビア状の微細気泡が均一核生成で表面上に形成され たと報告している. 急速加熱時の液体内の温度分布 は, 次式で与えられる.

$$
T(x, t)-T_{1}=4 k t i^{2} \operatorname{erf} c(x / 2 \sqrt{a t})
$$

一方, 高温面に噴流が衝突した直後からの表面温度 の変化と流動状況の変化は, 図 13 に示されるように

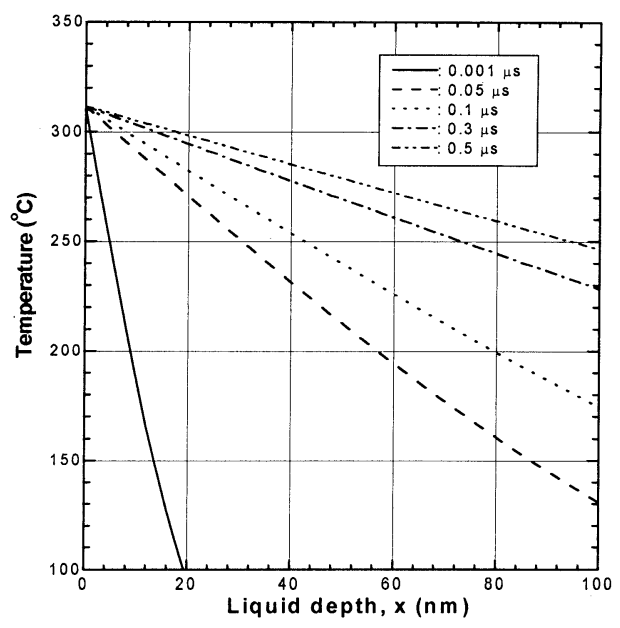

Fig. 14 Temperature distribution of liquid at different time of contact for quenching $350^{\circ} \mathrm{C}$-Steel block by $80 \mathrm{~K}$ jet [Ref.(10)]

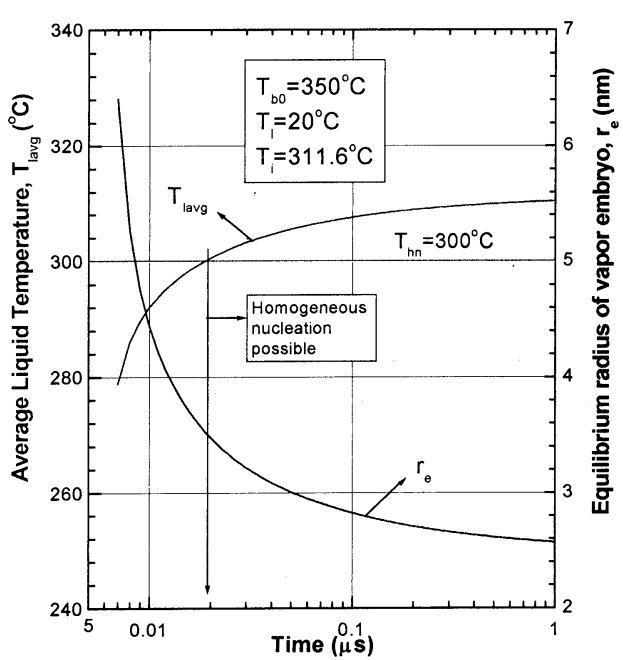

Fig. 15 Variation of average liquid temperature and equilibrium bubble radius with contact time [Ref.(10)]

変化する.

図 13 中の温度 $T_{\max }$ は, 半無限体の固液が接触した 瞬間の界面温度を液過熱限界温度と仮定したとき, 式 (1) から逆推定された接触直前の固体表面温度を示 す.また, 図中には, 炭素鋼の表面温度が, 丁度 $T_{\max }$ 温度を過ぎるときの流動状況が示されている．黄銅の 場合, 表面温度は, $T_{\max }$ 温度よりかなり高い温度とな っている. 従って, そこでの流動状況は, 依然として 激しい不規則な飛散となっている.

ところで, 噴流が高温面に接した直後の微小瞬間内 


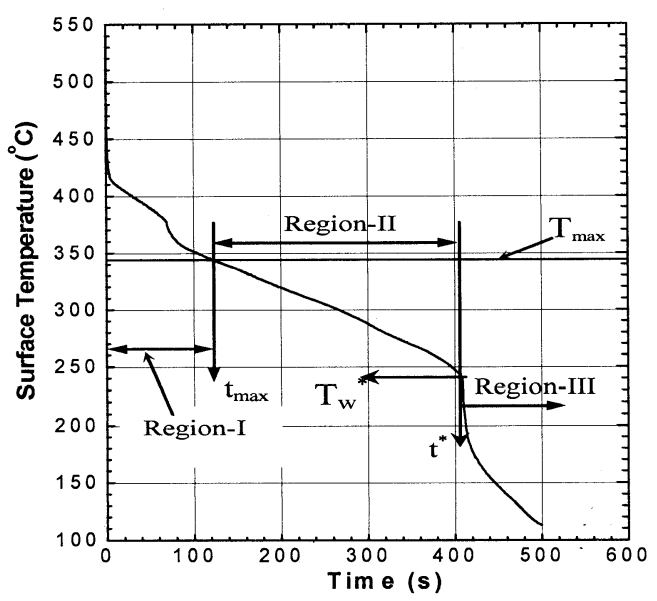

Fig. 16 Characteristics regions during jet impingement quenching [(Ref.(10)]

に形成される液内の温度分布は, 一次元半無限一様温 度であるという仮定をすると次式となる。

$$
\frac{T(x, t)-T_{1}}{T_{i}^{*}-T_{1}}=\operatorname{erfc}(x / 2 \sqrt{a t}) .
$$

もし，蒸気生成クラスターの大きさが定まるとクラ スター内の平均温度は式 $(7)$ を利用して次式のように 求めることができる。

$$
T_{\text {lavg }}(x, t)=\frac{1}{x_{\mathrm{e}}} \int_{0}^{x_{\mathrm{e}}} T(x, t) d x
$$

ここで, 距離 $x_{\mathrm{e}}$ は, クラスターの半径 $r_{\mathrm{e}}$ の 2 倍 $\left(x_{\mathrm{e}}=\right.$ $\left.2 r_{\mathrm{e}}\right)$ と仮定した. クラスターの半径は, 文献 (18)から 採用した。

$$
\begin{aligned}
& r_{\mathrm{e}}= \\
& \frac{2 \sigma}{P_{\text {sat }}\left(T_{\text {lavg }}\right) \exp \left[v_{1}\left\{P_{\propto}-P_{\text {sat }}\left(T_{\text {lavg }}\right)\right\} / R T_{\text {lavg }}\right]-P_{\propto}}
\end{aligned}
$$

図 14,15 は, $350^{\circ} \mathrm{C} の$ 炭素鋼を急速冷却したときの 液内の温度分布と平均温度とクラスターの大きさの変 化を示す。図 14,15 から, 平均温度が自発核生成温度 に到達する時刻は約 $0.02 \mu \mathrm{s}$ でその時のクラスターの 半径は, 約 $3.5 \mathrm{~nm}$ で分子の個数は 20 個程度となる. また，このクラスター内に蓄えられた内部エネルギー が断熱的に相変化するときになされる仕事によって激 しい液の飛散が引き起こされていると考えることが出 来るであろう。

ところで, 図 15 に示される核生成発生までの時間 $0.02 \mu \mathrm{s}$ における平均熱流束をここでの計算条件に対 して計算すると $q=518 \mathrm{MW} / \mathrm{m}^{2}$ となる。この值は， 分子運動論で決定され得る最大熱流束値 $\left(q_{\max }=214\right.$
$\left.\mathrm{MW} / \mathrm{m}^{2}\right)$ と比較すると約 2 倍程度大きい值となって いる. 大胆な近似にもかかわらず，2 倍程度の差は， 興味ある結果と考えられる。

なお，急速加熱の場合で，温度上昇は式（6)で与え られる。そのときの平均温度が自発核生成温度に到達 するまでには, 数 $\mu \mathrm{S}$ かかり, 高温面の固液接触に比較 して相対的に緩やかな液温上昇となる。

\section{4. 冷却曲線の特性領域}

衝突噴流を用いた高温面の冷却中の特性は，図 16 に示されるような 3 つの特性領域に分割することが出 来そうである.

領域 I：安定な固液の接触が出来ない領域

領域 II : 部分的に安定な濡れが始まるが，需れ面の拡 大が生じない領域

領域III：濡れ面の拡大が始まる領域 なお，高温面がほぼ一様に冷却されるミスト冷却では， 領域 II が現れにくく, 領域 I 〜領域IIIに直ちに推移し ている可能性が高いことを光武(21) は指摘している. その結果, 濡れ開始温度が液体の過熱限界温度 $T_{\mathrm{SH}}$ の近傍で生じている可能性もある.

\section{5. ま と め}

高温面の急速冷却や濡れに関する研究は, 数多くな されているが，ここでは著者が長年に亘って取り組ん できた衝突噴流による高温面の急速冷却に焦点を絞つ て，その伝熱特性について概説した。

濡れ開始と自発核生成温度の関連や決定条件につい ては，今後更に検討する必要がある.

おわりに, 本研究に推進に当たって, 協力していた だいた佐賀大学, 光武雄一准教授, Dr. P. Woodfield とバングラデシュ工科大学 Md A. Islam 教授に感謝 する.

\section{文献}

(1) Monde, M., Arima, H., Liu, W., Mitsutake, Y. and Hammad, J. A., An analytical solution for two-dimensional inverse heat conduction problems using Laplace transform, Trans. of JSME, Series B, Vol. 68, No. 666 (2002), pp. 473-480.

(2) Hammad, J., Monde, M., Mitsutake, Y. and Arima, H., Determination of surface temperature and heat flux using inverse solution for two dimensional heat conduction, Thermal Science \& Engineering, Vol. 10, No. 2 (2002), pp. 17-26.

(3) Woodfield, P. L., Monde, M. and Mitsutake, Y., Implementation of an analytical two-dimensional inverse heat conduction technique to practical problems, Int. J. of Heat and Mass Transfer, Vol. 49 (2006), pp. 187197. 
(4) Hammad, J., Mitsutake, Y. and Monde, M., Movement of maximum heat flux and wetting front during quenching of hot cylindrical block, Int. J. of Thermal Sciences, Vol. 43 (2004), pp. 743-752.

( 5 ) Hammad, J., Monde, M. and Mitsutake, Y., Characteristics of heat transfer and wetting front during quenching by jet impingement, Thermal Science \& Engineering, Vol. 12, No. 1 (2004), pp. 19-26.

(6) Mozumder, A. K., Monde, M. and Woodfield, P. L., Delay of wetting propagation during jet impingement quenching for a high temperature surface, Int. J. of Heat and Mass Transfer, Vol. 48 (2005), pp. 5395-5407.

( 7 ) Woodfield, P. L., Monde, M. and Mozumder, A. K., Observations of high temperature impinging-jet boiling phenomena, Int. J. of Heat and Mass Transfer, Vol. 48 (2005), pp. 2032-2041.

(8) Mozumder, A. K., Monde, M., Woodfield, P. L. and Islam, A., Maximum heat flux in relation to quenching of a high temperature surface with liquid jet impingement, Int. J. Heat Mass Transfer, Vol. 49 (2006), pp. 2877-2888.

(9) Mozumder, A., Woodfield, P. L., Islam, A. K. and Monde, M., Maximum heat flux propagation velocity during quenching by water jet impingement, Int. J. Heat Mass Transfer, Vol. 50, (2007), pp. 1559-1568.

(10) Islam, Md. A., Monde, M., Woodfield, P. L. and Mitsutake, Y., Jet impingement quenching phenomena for hot surfaces well above the limiting temperature for solid-liquid contact, Int. J. of Heat and Mass Transfer, Vol. 51 (2008), pp. 1226-1237.

(11) Shoji, M., Study of free liquid film flow (1st Rep. Experimental study of laminar free liquid film flow), Vol. 39, No. 321 (1973), pp. 1568-1577.
(12) Filipovic, J., Incropera, F. P. and Viskanta, R., Quenching phenomena associated with a water wall jet: 1 Transient hydrodynamic and thermal conditions, Experimental Heat Transfer, Vol. 8 (1995), pp. 97-117.

(13) Piggott, B. D. G., White, E. P. and Duffy, R. B., Wetting delay due to film and transition boiling on hot surfaces, Nuclear Engineering and Design, Vol. 36 (1976), pp. 169-181.

(14) Monde, M., Kitajima, K., Inoue, T. and Mitsutake, Y., Critical heat flux in a forced convection subcooled boiling with an impinging jet, Heat Transfer-1994, Vol. 7 (1994), pp. 515-520.

(15) Hall, D. E., Incropera, F. P. and Viskanta, R., Jet impingement boiling from a circular free-surface jet during quenching: part 1 -single-phase jet, $A S M E$ Journal of Heat Transfer, Vol. 123 (2001), pp. 901-910.

(16) Delale, C. F., Hruby, J. and Marsik, F., Homogeneous bubble nucleation in liquids: The classical revisited, $J$. of Chemical Physics, Vol. 118 (2003), pp. 792-806.

(17) Cole, R., Boiling Nucleation, Advanced in Heat Transfer, Vol. 10 (1974), pp. 86-116.

(18) Carey, V. P., Liquid-Vapor Phase-Change Phenomena, Taylor and Francis (Chapter 5), New York, (1992).

(19) Iida, Y., Okuyama, K. and Sakurai, K., Peculiar bubble generation on a film heater submerged in ethyl alcohol and imposed a high heating rate over $10^{7} \mathrm{Ks}^{-1}$, Int. J. Heat Mass Transfer, Technical notes, Vol. 36 (1993), pp. 2699-2701.

(20) Iida, Y., Okuyama, K. and Sakurai, K., Boiling nucleation on a very small film heater subcooled to extremely rapid heating, Int. J. Heat Mass Transfer, Vol. 37 (1994), pp. 2771 2780.

(21) Mitsutake, Y., Private communication (2007). 